\title{
The interactions between different types of financial and human resource slacks on firm performance: Evidence from a developing country
}

\author{
M.M. Fonseka ${ }^{a, b *}$, G-L. Tian ${ }^{b}$, X. Yang ${ }^{a}$ and R.L.T.N. Rajapakse ${ }^{b, c}$ \\ a. School of Business, Xi'an International Studies University, P.O. Box 84, Xi'an, 710128, Shaanxi, P. R. China \\ b. School of Management, Xi'an Jiaotong University, No. 28, Xianning West Road, Xi'an, 710049, Shaanxi, P. R. China \\ c. School of Power and Energy, Xi' an Jiaotong University, No. 28, Xianning West Road, Xi'an, 710049, Shaanxi, P. R. China \\ *To whom all correspondence should be addressed. \\ mohanfonseka@yahoo.co.uk; tian-gl@mail.xjtu.edu.cn; yangxia@xisu.edu.cn; thejarajapakse@yahoo.com
}

\begin{abstract}
This paper investigates the effect of both FS and HR slack together on firm performance and how different levels of these slack resources affect performance of private-owned enterprises (POEs) and state-owned enterprises (SOEs). Hypotheses are tested using a longitudinal data set of 11,985 listed Chinese companies from 2000 to 2009. Findings reveal that the unabsorbed-financial slack and HR slack show an inverse $U$ shape relationship on firm performance for both POEs and SOEs. However, a less-negative interaction occurs for unabsorbed-financial and HR slacks for POEs. The absorbedfinancial and HR slacks also shows an inverse $U$ shape relationship on performance and this relationship does not have a significant negative effect on SOE's performance. The article concludes with theoretical contributions and practical implications of the findings.
\end{abstract}

Authors wish to thank the participants at the Research Seminars at Xian Jiaotong University, China, and the Xi'an International Studies University, China for useful comments. This research has partially supported by the China Postdoctoral Science Foundation grant (2013M542360) and NSFC grant 71372163.

\section{Introduction}

Resource slack is potentially utilizable resources, which can be diverted or redeployed for the achievement of organizational goals (George, 2005). According to the organization theorists, slack resources despite the costs, strengthen firm's technical core, enhance firm performance (Cyert \& March, 1963; Pfeffer \& Salancik, 1986; Thompson, 1976), and provide flexibility when economic fluctuations threaten business environment. Some scholars argue that companies must maintain slack resources to protect and cushion their operating core from rapid changes in the external environment (Barnard, 1938; Rust \& Katz, 2002; Thompson, 1967) and slack resources help to reduce the need for making considerable changes to the operating core of the firm (Pfeffer \& Salancik, 1978; Rust \& Katz, 2002). On the other hand, agency theorists have cautioned that slack engenders agency problems; it causes inefficiencies in operations, hampers risk-taking, and reduces performance (Fama, 1980; Jensen \& Meckling; 1976).

To balance these two contrasting views, prior slack theorists suggested an inverse U-shaped slack-performance relationship (Bourgeois, 1981; Sharfman et al., 1988). In this relationship, the slack resource positively increases the firm performance up to a certain level. Thereafter, the relationship between slack and performance becomes negative, as businesses become complacent and they utilize their resources inefficiently. The financial slack (FS)performance relationship shows an inverse U-shape for firms in developed countries (Nohria \& Gulati 1996; George
2005; Kim, Kim \& Lee, 2008), and the same trajectory occurs in developing countries such as China's (Tan \& Peng, 2003; Ju \& Zhao, 2009; Quer, Claver \& Rienda, 2007; Wrigh, FilatotChe, Hoskissio \& Peng, 2005). Organizational efforts to enhance current performance explain the emergence of HR slack (Goerzen \& Beamish, 2007).

Efficiency gains engender HR slack, therefore firms acquire resources to expand/grow a business (Kor \& Mahoney, 2000), or safeguard to cope with external shocks. Some scholars argue that HR slack obstruct performance, especially when HR slack is associated with political and cognitive inertia that make expansion into new products or market is risky or unpopular (Hannan \& Freeman, 1989).

Based on behavior theory, scholars propose a positive relationship between FS and firm performance (George, 2005; Kim et al., 2008). Further, these studies reveal that an aforementioned relationship is linear in developed countries. Recent empirical studies investigated the relationship between HR slack and firm performance and found a negative relationship between HR slack and firm performance (Mishina, Pollock \& Porac, 2004; Voss, Sirdeshmukh \& Vos, 2008). The limited number of researches has undertaken empirical studies to investigate HR slack-firm performance in developing countries. In this study, we investigate the effect of both FS and HR slack together on firm performance in a developing country.

HR functions (such as recruitment, training, development, compensation, and retention of skilled employees) are costly and directly related to financial resources. Wang et al. 
(2013) point out that FS available for $R \& D$ investment enables employees to anticipate reward, such as remuneration for performance and financial incentives for their human capital in order to offer of an attractive reward to become a commitment, the R\&D activities devoted for knowledge creation have to be supported by firm financial budget. Compared with their counterparts, private-owned firms in China face more constraints in financial resources in the areas of market economies, performance, and competitive advantage (Peng \& Heat, 1996). Furthermore, these two types of ownerships (i.e. POEs and SOEs) possess heterogeneous institutional advantages and disadvantages according to the different decision making behaviors (Boisot \& Child, 1996; George, 2005; Tan \& Peng, 2003). Thus, when achieving performance goals, firms with diverse ownership types are likely to make different resource allocation decisions and have different efficiencies in resource utilization (Ju \& Zhao, 2009). Hence, it is worth to investigate the impact of FS and HR slack on firm performance in different types of ownerships.

Wang et al. (2013) point out that some scholars (Mishina et al., 2004; Voss et al., 2008) have differentiated types of slack recently. In prior studies, findings related to HR slack and FS were not conclusive. They have drawn different implications for the two types of slack. For example, Mishina et al. (2004) suggest that while HR slack inhibits product expansion, FS facilitates it. In the same way, Voss et al. (2008) find that the HR slack is positively associated with product exploitation; however FS is not significantly associated with it. Although firms need access to different types of resources at the same time to ensure their growth and development (Cooper, Gimenogascon \& Woo, 1994; Ndofor \& Levitas 2004), no comprehensive single study has investigated the impact of both FS and HR slack together on firm performance in a developing country. Based on the above arguments, we suggest that the two types of slack resources affect firm performance differently. Most studies in developed countries have investigated the impact of only one type of slack resource either FS or HR slack on firm performance. Hence, the present study addresses these research gaps.

SOEs have over staff as state-assigned managers act in the interests of the politicians who control them (Shleifer \& Vishney, 1994). Furthermore, politically connected CEOs try to solve local unemployment problems and recruit extra staff to comply with government policies of increasing employment opportunities (Fan, Wong \& Zhang, 2007). Although this conflict arises occasionally in developed countries, it has become more frequent in China, but less likely in Chinese POEs (Fan et al. 2007). Tsai (2008) found that, in China, compared with developed countries, the state holds a significant stake, and the Chinese government has a much greater influence over company operations. SOEs in China generally maintain large inventories of slack resources (Aharoni, 1986; Kornai, 1992; Peng \& Heat, 1996; Tan, 2003). They enjoy privileged status over the POEs as they have acquired less-costly state-appropriated capital goods, enabling them to hoard slack resources (Tan, 2003). Hence, it is vital to understand the effects of FS and
HR slack for different ownership structures such as SOEs and POEs. In particular, the literature has also failed to examine difference effects of FS and HR slack for ownership structures in a developing country. Thus we address these significant research gaps and extend previous research related to a developing country.

Our findings help to explain the role of both FS and HR slack together on firm performance and to restructure the slack resources of SOEs in China. International firms that must interact, compete, and collaborate with Chinese firms should benefit from better understandings of China's economic growth (Child \& Tse, 2001; Luo \& Peng, 1999; Tan, 2002; Yan \& Gray, 1994). Many top managers of Chinese firms need to understand how both FS and HR slack together affect firm performance, whether the interaction inhibits or constrains firm performance, whether HR slack abandon or keep with the firm and FS deployed.

\section{Theoretical background and hypotheses}

Slack resource is defined as a "collection of resources in an organization that is in excess of the minimum necessary to produce a given level of organizational output" (Mellahi \& Wilkinson, 2010 ; Nohria \& Gulati, 1996: 1246). Researchers have examined the association between slack resource and risk taking (Wiseman \& Bromiley, 1996), innovation (Greve, 2003; Nohria \& Gulati, 1996), firm growth (Mishina et al., 2004), and performance (Bromiley, 1991; Love \& Nohria, 2005; Miller \& Leiblein, 1996; Tan \& Peng, 2003; Wiseman \& Bromiley, 1996). Tan and Peng (2003) suggest different impacts of absorbed and unabsorbed slack on firm performance. Unabsorbed slack is referred to firm's present uncommitted resources that can be more easily redeployed elsewhere, allowing for greater managerial discretion in a short-term (Sharfman et al., 1988; Tan \& Peng, 2003). Absorbed slack refers firm resources that cannot easily recover (Sharfman et al., 1988).

Some empirical studies have reported a positive-linear relationship between slack resources and firm performance (Daniel, Lohrke, Fornaciari \& Turner, 2004), while others have observed a curvilinear relationship (George, 2005). Other studies have demonstrated an inverted U-shaped relationship between the slack resource and performance (Geiger \& Cashen, 2002; Nohria \& Gulati, 1996). Thus, there appears to be no conclusive evidence about the relationship both FS and HR slack together on firm performance.

In line with behavioural theorists, FS and HR slack will affect firm performance positively. Firms may use FS to recruit new employees or to train existing staff to pursue emerging business opportunities. Firms use HR slack to enhance their current operations (Goerzen \& Beamish, 2007). HR slack that arises from efficiency gains provides a resource cushion for growth, (Kor \& Mahoney, 2000) and helps firms to cope with external shocks (Rust \& Katz, 2002). A number of empirical studies have supported behavioral theorists' arguments, which show slack resources 
help to increase firm performance (Argote \& Epple, 1990; Li \& Rajagopala, 1998; Yelle, 1979; Wiersma, 2007).

Entrepreneur theorists argue that highly ambitious managers are motivated to exploit slack resources to expand their market or product positioning, and they use slack resources for gain higher profitability, despite additional costs (Pitelis, 2007). Favourable new market opportunities inspire managers to expand their business. Firm may use FS for recruiting new employees and training new recruited and existing employees. Hence, firms with FS have advantage over others, and the presence of both FS and HR slack may exert positive effects. Entrepreneurial managers intensively utilize slack resources to respond to environment turbulence (Mishina, et al., 2004) and exploit new market opportunities (Cheng \& Kesner, 1997). Firms with more FS and HR slack enjoy competitive advantage as competitors cannot use same resource configurations or copy their strategies (Mishina, et al., 2004).

Acting quickly is important because immediate action is associated with long-term advantages including dominant and enduring market positions that originate from competitive head starts (Kerin, Varandarajan \&Peterson, 1992). According to the behavioral theorists, firms with both FS and HR slack can pursue value-creating opportunities more rapidly than other firms. Certainly, firms with FS and HR slack can pursue more new opportunities rapidly because they have no resource constraints. However, agency theorists view firms as independent legal entities that have contracts between principals and agents (Fama, 1980). They believe that maintaining slack resources benefits only to the managers acting as agents who may use slack resources to facilitate excessive investment (Jensen \& Meckling, 1976). Thus slack resources create an agency problem and that leads to low efficiency, inhibit risk-taking, and reduces performance (Jensen \& Meckling, 1976).

According to the resource constraint theory, we argue that the effect of both FS and HR slack together on firm performance is positive. Moreover, Baker and Nelson (2005) Starr and MacMillan (1990) and Mosakowski (2002) argue that resource constraints in multiple domains may harm development of firm. Excess resources may cause managers to become complacent, risk averse, and focused inwardly to protect their current positions (Stevenson 1983; Stevenson \& Jarillo 1990). HR slack resources are not always better for firm growth (Mishina et al., 2004). HR slack is "stickier" than FS and not easily (re)deployed for alternative uses (Mishina et al., 2004; Voss et al. 2008). This implies that HR slack is context dependent and more closely tied to organizational routines that constrain growth in new areas that require different skills or HR configurations (Mishina et al., 2004). In this perspective, the relationship between slack resources and firm performance will not be determined by the amount and characteristics of slack resources (Voss et al., 2008). Firms with more HR slack may be constrained by the skills and domains of their existing employees for exploring new opportunities even though the firm has ability to invest their FS. HR slack may obstruct firm performance, especially when it is associated with political motivation and cognitive inertia (Hannan \& Freeman, 1989).

Thus, considering above arguments, we hypothesize that interaction between FS and HR slack lead to the following hypothesis:

H1: Interaction between financial and human resource slacks has curvilinear relationship with firm performance. This means that presence of too little or too much financial and human resource slacks at the same-time have negative relationship with performance. On the other hand, presence of moderate level of financial and human resource slacks at the same-time have positive relationship with performance.

\section{Effect of firm ownership}

The ownership type represents its unique characteristics and structure and can reflect its distinct identity (Hannan \& Carroll, 1992) and organizational diversity (Peng, Tan \& Tong, 2004; Tan, 2002). Ownership types evoke different institutional constraints and advantages (Gao, Murray, Kotabe \& Lu, 2010; Peng et. al., 2004; Shenker \& Von Glinow, 1994; Ju \& Zhao, 2009).

In China, there are two main types of ownership in public quoted companies, namely POE and SOE. SOEs tend to have relatively similar organizational structures and processes; they are larger and more complex than POEs and usually laden with a variety of resources (Peng et al., 2004) including cash, raw material, and human resources (Child, 1994; Tan, 2003). POEs operate with tighter budget constraints in increasingly competitive markets (Perkins, 1994). POEs tend to make better use of their limited resources (Li \& Zhang, 2007; Peng et al. 2004; Tan, 2002). Tsai (2008) points out that state hold significant stake and government of China has a much greater influence than developed counties. Government support helps to accumulate abundant resources for SOEs, so their foremost problem is inefficiency. In most previous studies, organizational slack and firm performance primarily focus on either POE or SOE (Peng, 2004). Research related to FS and firm performance has considered ownership type as a moderate variable (Ju \& Zhao, 2009) and HR slack and firm performance has also considered ownership type as a moderate variable (Fonseka et al., 2013). However, fresh investigation is needed to determine moderating effect of ownership between slack resources (i.e. both FS and HR slack) and firm performance.

Dunk (1993) found that when information asymmetry was high, firm led to a reduction in slack. Information asymmetries problem is higher in POEs than SOEs in China. Potential employees find it difficult to evaluate young POEs because they have highly uncertain prospects. Moreover, compared with their more established counterparts, young and small POEs often lack the visibility and reputation that is often the first prerequisite for mobilizing employees (Williamson, 2000). Absorbed slack resources may 
constrain POEs and reduce their adaptive responses to business opportunities, decrease their flexibility, and decline their performance (Tan, 2002). On the other hand, unabsorbed slack resources in POEs help to improve performance (Ju \& Zhao, 2009). Hence, ownership types will experience different impacts on FS and HR slack. These arguments lead to the following hypothesis:

H2: POEs will show a less-negative interaction for financial and human resource slacks on firm performance than SOEs.

\section{Method}

\section{Data and Sample}

For this study, we used all listed Chinese companies (except financial industry code - I) in the China Stock Market and Accounting Research (CSMAR) database from 2000 to 2009. We also excluded foreign-listed Chinese firms, firms listed on the Hong Kong stock market, and firms with missing data. The final sample included 11,985 firm-year observations.

\section{Measures}

Scholars were suggested various measurements for slack resources and it is a difficult task to choose appropriate operationalizations (Mishina et al., 2004). The accumulation of slack resources depends on firm's prior performance. Hence, prior performance should be controlled. Then, we follow the one-year lag structure for profitability (Bromiley, 1991; Tan, 2003).

\section{Explanatory variables}

Financial slack: We use Singh's conceptualization because it provides the most widely used measurements of FS (Ju \& Zhao, 2009), and the most verifiable indicators of managerial behaviors (Bourgeois, 1981; Tan \& Peng, 2003). To measure absorbed-FS, we used the ratio of sales expenses, general expenses, and administrative costs to total sales. Unabsorbed-FS is measured by quick ratio, which is ratio of cash flow and marketable securities in each year to current liabilities (Ju \& Zhao, 2009).

HR slack: Researchers commonly use employee productivity as a proxy for measuring HR slack (Greenly \& Oktemgil, 1998; Datta, Guthrie \& Wright, 2005; Huselid, 1995; Koch \& McGrath, 1995; Kroll, 2006; Mishina et al., 2004; Welbourne, Neck, \& Meyer, 1999). Many empirical researchers have used revenue per employee to measure how effectively employees generate operating income (Kroll, 2006), measured by dividing total sales by number of employees (Datta et al., 2005; Huselid, 1995; Koch \& McGrath, 1995). HR slack is measured by changing employee productivity at the organization level to employee productivity at the industry level (Mishina et al., 2004). We measured HR slack following Miller and Leiblein's suggested approach (Miller and Leiblein (1996). We measured HR slack (HRS) of $\mathrm{i}^{\text {th }}$ firm at $\mathrm{t}^{\text {th }}$ year as follows:

$$
H R S_{i t}=\left(\frac{I S_{i t}}{I E_{i t}}\right)-\left(\frac{S_{i t}}{E_{i t}}\right)
$$

Where $\mathrm{IS}_{\mathrm{it}}$ is the total industry sales, $\mathrm{IE}_{\mathrm{it}}$ is an industry's total number of employees, $S_{i t}$ is firm $i^{\text {th }}$ total sale at the time of $t$ and $E_{i t}$ is $i^{\text {th }}$ firm's total number of employees at the time of $t$. The industry classification is based on that of the China Security Regulatory Commission (CSRC). We divided the sample into 21 industries with non-manufacturing industries given a one-digit code and manufacturing industries a twodigit code (Wu, Wu \& Rui, 2010).

Ownership types: Ownership type (OWN) is measured using a dummy variable; if the largest controlling shareholder is the government, ownership is assigned one; zero indicates privately owned firms (Wu \& Pangakar, 2010; Wu, Xu, \& Phan, 2011).

\section{Control variables}

We also used age, size, debt ratio, industry type, and year dummy as control variables. Firm size (SIZE) is measured in terms of the natural logarithm of total assets; age (AGE) is measured as number of years since incorporation. Industry type (IND) is measured as a categorical variable that represents all industry classifications in accordance with CSRC. Scholars note that firm age, size, industry types (Tan \& Peng, 2003; Pang, Shen \& Li, 2011; Markman \& Gartner, 2002; Mishina et al., 2004), and debt ratio (Ju \& Zhao, 2009) greatly influence firm performance. Firm size is likely to relate to HR slack (George, 2005; Love \& Nohira, 2005). The nature of the industry and its level of turbulence complexity affect how much slack the firm has for insulation or for seizing industry opportunities (Aldrich, 1980). Slacks correlate differently with performance in a variety of industries (Miller et al., 1996). A firm that has existed longer has more opportunities to create links, networks, and contingency plans as part of their slack resource system (Sharfman et al., 1988). We use industrytype and time dummy variables to control industry and yearfixed effects. However, we do not report them with the results of the models.

\section{Dependent Variable}

Firm Performance: Following Bromiley (1991), Pang et al. (2011), Su, Xie and Lie (2009), Tan and Peng (2003), Ju \& Zhao (2009) and Zhang (2006), We use the accountingbased performance measure; Return on Investment (ROI).

\section{Analysis}

Using a longitudinal data set, we investigate the levels of FS and HR slack influence on firm performance and study how different levels of these slack resources affect performance of private-owned enterprises (POEs) and state-owned 
enterprises (SOEs). The ordinary least squares (OLS) regression model to estimate panel data can cause bias from unobserved heterogeneity (Green, 2000). Hence, we used general least square (GLS) models for hypotheses testing. GLS transforms original variables to satisfy the standard least-square assumptions and modified emergence of heteroscedasticity and autocorrelation problems in timeseries data (Green, 2000). We calculate variance inflation factor (VIF). We checked for multicollinearity problem; VIF derived from OLS regression. The VIF ranged from 1.06 to 2.40. Hence, multicollinearity was unlikely a serious problem in this study.

\section{Results}

Table 1 shows descriptive and correlation statistics for the variables. We find some preliminary evidence suggest that FS (absorbed and unabsorbed) and HR slack show positive associations with performance. Correlations among the variables are less than 0.5. However, descriptive and correlation statistics alone are inadequate to explain the levels of FS and HR slack influence on performance.

Table 1: Descriptive statistics and correlation matrix

\begin{tabular}{|c|c|c|c|c|c|c|c|c|c|c|}
\hline Variables & ROA & 1 & 2 & 3 & 4 & 5 & 6 & 7 & 8 & 9 \\
\hline Performance (ROI) & 1 & & & & & & & & & \\
\hline 1 Firm age & $-0.103 *$ & 1 & & & & & & & & \\
\hline 2 Firm size & $0.253 *$ & $0.047 *$ & 1 & & & & & & & \\
\hline 3 Debt ratio & $-0.411 *$ & $0.116^{*}$ & 0.008 & 1 & & & & & & \\
\hline 4 Ownership & $0.040 *$ & $-0.120 *$ & $0.179 *$ & $-0.068 *$ & 1 & & & & & \\
\hline $\begin{array}{l}5 \text { Absorbed financial slack } \\
\text { (AFS) }\end{array}$ & $0.377 *$ & $-0.130 *$ & $0.139 *$ & $-0.423^{*}$ & $0.035 *$ & 1 & & & & \\
\hline $\begin{array}{l}6 \text { Unabsorbed financial } \\
\text { slack (UAFS) }\end{array}$ & $0.229 *$ & $-0.138 *$ & $-0.063 *$ & $-0.412 *$ & 0.006 & $0.3176^{*}$ & 1 & & & \\
\hline $\begin{array}{l}9 \text { Human resource slack } \\
\text { (HRS) }\end{array}$ & $0.082 *$ & 0.011 & $-0.049 *$ & -0.009 & $-0.021 *$ & $0.022 *$ & -0.018 & $-0.068 *$ & -0.016 & 1 \\
\hline Mean & 0.017 & 9.935 & 21.236 & 0.239 & 0.678 & 0.104 & 0.513 & 0.255 & 1.086 & 0.264 \\
\hline Standard Deviation & 0.096 & 4.178 & 1.003 & 0.169 & 0.467 & 1.480 & 0.695 & 0.442 & 0.995 & 0.945 \\
\hline
\end{tabular}

Note. * denotes all significant coefficients at the 0.05 significant level or below. We use standardized data at 0.01 level.

Table 2 shows the effects of FS and HR sack on firm performance. We employ hierarchical multiple linear regressions models. Model 1 includes only control variables. Adding the slack measures and their squared terms significantly increases the goodness-of-fit when compared with Model 1. In Model 4, we test FS and HR slack interactions. In Model 5, we conjecture a three-way interaction of ownership type, FS, and HR slack. Models 1, 2, and 3 support the previous research findings; FS and HR slack have a curvilinear relationship to firm performance, and control variables affect firm performance. Hence, we limit the discussion to Models 4 and 5.

Table 2: Regression analysis result of human resource, financial slacks, and their interaction and firm performance

\begin{tabular}{|c|c|c|c|c|c|c|c|c|c|c|}
\hline \multirow{2}{*}{$\begin{array}{l}\text { Variables } \\
\text { Constant }\end{array}$} & \multicolumn{2}{|l|}{ Model 1} & \multicolumn{2}{|l|}{ Model 2} & \multicolumn{2}{|l|}{ Model 3} & \multicolumn{2}{|c|}{ Model 4} & \multicolumn{2}{|c|}{ Model 5} \\
\hline & $-0.423^{* * *}$ & $(0.018)$ & $-0.407^{* * *}$ & $(0.018)$ & $-0.401 * * *$ & $(0.018)$ & $-0.403 * * *$ & $(0.018)$ & $-0.403^{* * *}$ & $(0.018)$ \\
\hline Firm age & $-0.002 * * *$ & $(0.000)$ & $-0.001^{* * *}$ & $(0.000)$ & $-0.001 * *$ & $(0.000)$ & $-0.001^{* *}$ & $(0.000)$ & $-0.001 * *$ & $(0.000)$ \\
\hline Firm size b & $0.025 * * *$ & $(0.001)$ & $0.022 * * *$ & $(0.001)$ & $0.020 * * *$ & $(0.001)$ & $0.021 * * *$ & $(0.001)$ & $0.021 * * *$ & $(0.001)$ \\
\hline Debt ratio c & $-0.230^{* * * *}$ & $(0.004)$ & $-0.172 * * *$ & $(0.005)$ & $-0.158 * * *$ & $(0.005)$ & $-0.159 * * *$ & $(0.005)$ & $-0.159 * * *$ & $(0.005)$ \\
\hline Ownership d & $-0.011^{* * * *}$ & $(0.002)$ & $-0.009^{* * *}$ & $(0.002)$ & $-0.010^{* * *}$ & $(0.002)$ & $-0.011 * * *$ & $(0.002)$ & $-0.010^{* * *}$ & $(0.002)$ \\
\hline AFS & & & $0.013^{* * * *}$ & $(0.001)$ & $0.005^{* * *}$ & $(0.001)$ & $0.005^{* * *}$ & $(0.001)$ & $0.005^{* * *}$ & $(0.001)$ \\
\hline UAFS & & & $0.007 * * * *$ & $(0.001)$ & $0.041 * * *$ & $(0.003)$ & $0.041 * * *$ & $(0.003)$ & $0.041 * * *$ & $(0.003)$ \\
\hline AHRS & & & $0.009^{* * * *}$ & $(0.001)$ & $0.027^{* * *}$ & $(0.002)$ & $0.028^{* * *}$ & $(0.002)$ & $0.028^{* * *}$ & $(0.002)$ \\
\hline AFS (Squared) & & & & & $-0.004 * * *$ & $(0.000)$ & $-0.004 * * *$ & $(0.000)$ & $-0.001^{* * *}$ & $(0.000)$ \\
\hline UAFS (Squared) & & & & & $-0.001 * * *$ & $(0.000)$ & $-0.001 * * *$ & $(0.000)$ & $-0.008 * * *$ & $(0.001)$ \\
\hline HRS (Squared) & & & & & $-0.008^{* * * *}$ & $(0.000)$ & $-0.008^{* * *}$ & $(0.001)$ & -0.004 & $(0.000)$ \\
\hline AFS $x$ HRS & & & & & & & $-0.003 * * *$ & $(0.000)$ & $-0.002 * * *$ & $(0.000)$ \\
\hline UAFS $\times$ HRS & & & & & & & $-0.002^{* *}$ & $(0.001)$ & $-0.001 * *$ & $(0.001)$ \\
\hline AFS x HRS * Ownership & & & & & & & & & -0.001 & $(0.001)$ \\
\hline UAFS $\times$ HRS $*$ Ownership & & & & & & & & & $-0.004 *$ & $(0.002)$ \\
\hline $\mathrm{N}$ & 11985 & & 11985 & & 11985 & & 11985 & & 11985 & \\
\hline Log-likelihood & 12887.43 & & 13394.91 & & 13596.89 & & 13643.56 & & 13646.77 & \\
\hline Wald $\mathrm{Chi}^{2}$ & $4103.48 * * *$ & & $5156.16^{* * * *}$ & & $5744.11 * * *$ & & $5882.79 * * *$ & & $5892.38^{* * * *}$ & \\
\hline
\end{tabular}

Note. + denotes significant at $0.1, *$ for significance at $0.05, * *$ for significance at 0.01 , and *** for significance at 0.001. Standard errors are in parentheses 
The findings indicate that FS exhibited a curvilinear relationship with firm performance. The coefficient of both absorbed- and unabsorbed- FS are significantly positive (for absorbed $\beta=0.005 ; p<0.001$; unabsorbed $\beta=0.041 ; p<$ $0.001)$. Its squared term is negative and statistically significant (for absorbed $\beta=-0.004 ; p<0.001$; for unabsorbed $\beta=-0.001 ; p<0.001)$. The results also strongly indicate that HR slack exhibited a curvilinear relationship with firm performance. These results are mostly aligned with previous studies which arguing for an inverse U-shaped relationship between FS and performance, and also indicate that slack theories work equally well for HR slack. We find significantly negative interaction between absorbed-FS and HR slack $(\beta=-0.003 ; p<0.001)$, and significantly negative interaction between unabsorbed-FS and HR slack $(\beta=$ $0.002 ; p<0.001)$. This evidence supports hypothesis 1 .

We rely on a surface plot to explain relationship between absorbed-FS and HR slack, as illustrated in Figure 1. For low levels of absorbed-FS, a positive effect of HR slack on performance occurs but levels off as HR slack increases. For mean levels of absorbed-FS, HR slack insignificantly affects performance. However, HR slack has an increasingly negative effect for high levels of absorbed-FS. Figure 1 provides additional supporting evidence for hypothesis 1 . It reveals that both high levels and low levels of absorbed-FS and HR slack is negatively influenced firm performance. Figure 2 shows a surface plot of absorbed-FS and HR slack. Similarly, the both high levels of unabsorbed-FS and HR slack and low levels of unabsorbed-FS and HR slack is also negatively influenced firm performance.

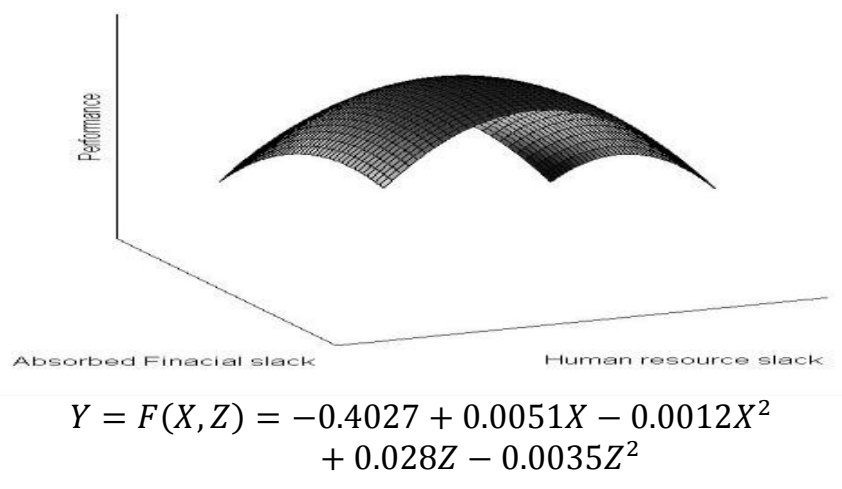

where: $\quad \mathrm{Y}=$ Performance

$\mathrm{X}=$ Absorbed financial slack

$\mathrm{Z}=$ Human resource slack

Figure 1: Curvilinear relationship between absorbed financial, human resource slacks and firm performance

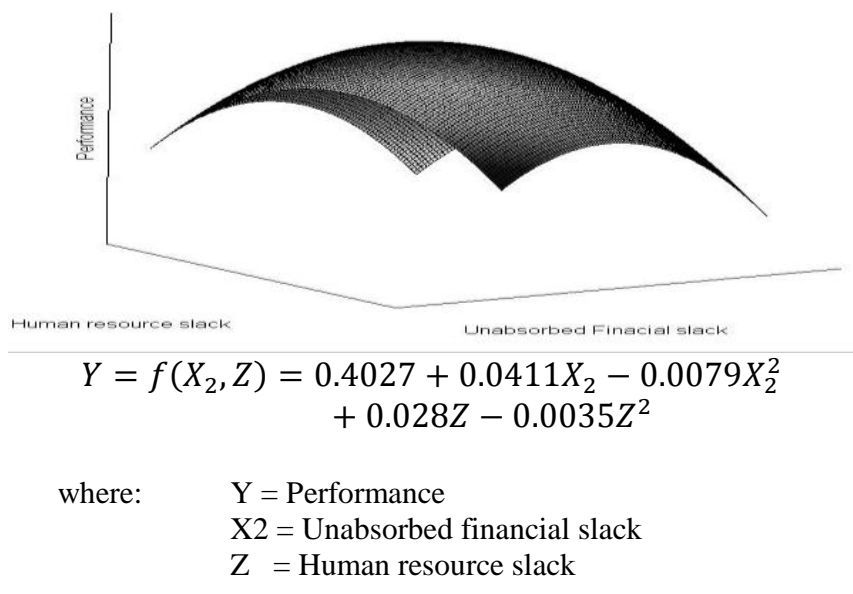

Figure 2: Curvilinear relationship between unabsorbed financial, human resource slacks and firm performance

In Model 5, we test the three-way interaction of ownership type, FS, and HR to test Hypotheses 2. The interaction of Absorbed-FS and HR slack show no different on performance for different ownership types. However, the interaction of unabsorbed-FS and HR slack affect firm performance differently for different types of ownership. POEs, compared with SOEs, show less-negative interactions of unabsorbed-FS and HR slack.

\section{Discussion}

The results indicate that different type of FS and HR slack exhibited an inverse U-shaped relationship with firm performance. This finding echoes previous studies on FS (Tan \& Peng, 2003; Ju \& Zhao, 2009; Quer et al., 2007; Wrigh et al., 2005). We newly exposed HR slack for China, and it supports claims of early slack theorists (Bourgeois, 1981; Sharfman et al., 1988).

We make three contributions to the slack resources literature with this study. Our findings show both high and low levels of FS and HR slack are negatively influenced firm performance. This finding is in line with resource constraint theory, which indicates that FS and HR slack abundance does not guarantee for better performance, but that resource constraints in financial and HR may also harmful for firm performance. Specifically, we demonstrate that in our sample firms having both high levels of FS and HR slack or low levels of FS and HR slack are detrimental for firm performance. This insight explains why results differ in findings of previous studies focused on China. The SOEs have both high levels of FS and HR slack, which may cause greater inefficiencies, and agency problems. The both high levels and low levels of unabsorbed-FS and HR slack is more critical to current performance, compared to the absorbed-FS and HR slack, which belongs to previously devoted resources. On the other hand, unabsorbed-FS and HR slack have an interaction that is more important for future performance.

The interaction of absorbed-FS and HR slack does not affect the performance of different ownership types differently. 
POEs show a less-negative interaction of unabsorbed-FS and HRS, while SOEs show a more-negative interaction effect between FS and HR slack on firm performance. HR slack may be especially harmful when firms have abundant FS, which explain why these results differ from findings of previous studies focusing on FS and HR slack separately. Hence, those previous studies cannot capture interaction effects of different slack resources. Previous research has shown that SOEs have richer FS and HR slack because of state support and favorable access to these resources. SOEs are more likely to be located at the high-end of the FS continuum, which may lead to inefficiencies and agency problems.

\section{Implications}

This study has significant implications for managerial practice and policymakers' decision making. The managers should consider organizational slack profoundly as abundant financial slacks may cause danger to firm success. Firms will benefit from efficient and effective (timely) capital investments and management of scare resources. Managers who raise financial resources from external parties (such as investors and lenders) should be particularly cautious in using liquidity (e.g., cash) resources, because less-efficient use of liquidity resources may potentially endanger their relationship with stakeholders and increase financing costs. If firms cannot attract sufficient financial and HR, performance will deteriorate. They may also desire to keep some financial resources, especially unabsorbed-FS, as a buffer. However, keep large amount of FS and HR slacks are also not benefited.

Our findings may help government authorities understand the need to further broaden policy measures targeted toward more-efficient utilization of slack resources, both FS and HR slack. Although current policies have largely focused on increasing financial resources and using firms to generate employment in China, this research indicates that policy measures allowing firms to mobilize slack resources are also beneficial. Governmental efforts to use SOEs especially to provide jobs can negatively affect their performance. Firms must keep optimum levels of FS and HR slack for better performance because too height or low levels of FS and HR slack deteriorate firm performance. Such attention will especially enhance SOE performance.

\section{Limitations and future research directions}

This research has some inherent limitations that lead to fruitful future research. Our focus on SOEs and POEs ignores the rich diversity in China's organizational landscape, including "hybrid" ownerships such as foreignowned, joint stock, and venture capital-backed firms. Further research is also needed to examine contextual robustness.

\section{Conclusion}

In this study, we aim to investigate how the interaction between different types of FS and HR slack influences firm performance, and how different levels of these slack resources affect performance of POEs and SOEs. We use a large longitudinal data set of listed companies in China and found that the both high and low levels of unabsorbed-FS and HR slack, and both high and low levels of absorbed-FS and HR slack are negatively influenced firm performance. Absorbed-FS and HR slack do not affect firm performance differently for different ownership types: POEs or SOEs. For POEs, a less-negative interaction occurs for unabsorbedFS and HR-slacks. SOEs show higher-negative interaction between FS and HR slack on performance than their POE counterparts.

Resource constraint theories support the finding that resource abundance is no guarantee for success and that resource constraints in too many domains may also hinder development. Apparently, firm performance is damaged for firms with either high or low levels of FS and HR slack. HR slack is especially harmful when firms have abundant FS. This insight explains why finding of this study is different from previous studies in context of developing countries. SOEs have high levels of FS and HR slack, which may cause greater inefficiencies and agency problems. However, the negative interaction between absorbed-FS and HR slack is more critical to performance, compared with the interaction between unabsorbed-FS and HR slack. On the other hand, interaction between unabsorbed-FS and HR slack is important for better performance in the future. We explored these insights and their implications for managerial practice and discussed the theoretical contributions of these findings.

\section{References}

Aharoni, Y. 1986. The evolution and management of state owned enterprises. Cambridge, MA.: Ballinger.

Aldrich, H. 1980. Organizations and environments. New York: Prentice-Hall.

Argote, L. \& Epple, D. 1990. 'Learning curves of manufacturing', Science, 247: 920-924.

Baker, T. \& Nelson, R. E. 2005. 'Creating something from nothing: Resource construction through entrepreneurial bricolage', Administrative Science Quarterly, 50(3): 329366.

Barnard, C.I. 1938. The functions of the executive. Cambridge, MA :Harvard University Press.

Boisot, M. \& Child, J. 1996. 'From fiefs to clans and network capitalism: Explaining China's merging economic order', Administrative Science Quarterly, 41(4): 600-628. 
Bourgeois, L.J. 1981. 'On the measurement of organizational slack', Academy of Management Review. 6(1): 29-39.

Bourgeois, L.J. \& Singh, J.V. 1983. 'Organizational slack and political behavior of top management teams'. Proceedings: Academy of Management, 43: 43-47.

Bromiley, P. 1991. 'Testing a causal model of corporate risk taking and performance', Academy of Management Journal, 34: 37-59.

Cheng, J.L.C. \& Kesner, I.F. 1997. 'Organizational slack and response to environment shift: The impact of resource allocation pattern', Journal of Management, 23 (1), 1-18.

Child, J. 1994. Management in China during the age of reform. Cambridge: Cambridge University Press.

Child, J. \& Tse, D.K. 2001. 'China's transition and its implications for international business', Journal of International Business Studies, 32: 5-21.

Cooper, A., Gimenogascon, F. \& Woo, C. 1994. 'Initial human and financial capital as predictors of new venture performance', Journal of Business Venturing, 9: 371-395.

Cyert, R.M. \& March, J.G. 1963. A behavioral theory of firms. New Jersey: Prentice-hall Inc.

Daniel, F., Lohrke, F. T., Fornaciari, C. J., \& Turner, J.R.A. 2004. 'Slack resources and firm performance: A metaanalysis', Journal of Business Research, 57: 565-574.

Datta, D.K., Guthrie, J.P. \& Wright, P.M. 2005. 'Human resource management and labor productivity: Does industry matter?' Academy of Management Journal, 48(1): 135-145.

Dunk, A.S. 1993. 'The effect of budget emphasis and information asymmetry on the relation between budgetary participation and slack', The Accounting Review, April: 400-410.

Fama, E. 1980. 'Agency problem and theory of the firm', Journal of Political Economy, 88: 288-298.

Fan, J.P.H, Wong, T.J. \& Zhang, T. 2007. 'Politically connected CEOs, corporate governance, and post-IPO performance of China's newly partially privatized firms', Journal of Finance Economic, 84: 330-358.

Fonseka, M.M., Wang, P. \& Manzoor, M.S. 2013. 'Impact of human resource slacks on firm performance: Evidence from a developing country', Zbornik radova Ekonomskog fakulteta $u$ Rijeci/ Proceedings of Rijeka Faculty of Economics, 31(2): 271-301.

Gao, G.Y., Murray, J.Y., Kotabe, M. \& Lu, J. 2010. 'A strategy tripod perspective on export behaviors: Evidence from domestic and foreign firms based in an emerging economy', Journal of International Business Studies, 41(3):377-396.
Geiger, S.W. \& Cashen, L.H. 2002. 'A multidimensional examination of slack and its impact on innovation', Journal of Managerial Issues, 14: 54-68.

George, G. 2005. 'Slack resources and the performance of privately held firms', Academy of Management Journal, 48(4): 661- 676.

Goerzen, A. \& Beamish, P.W. 2007. 'The Penrose effect: Excess expatriates in multinational enterprises', Management International Review, 47(2): 221-239.

Greene, W.H. 2000. Econometric analysis. $4^{\text {th }}$ Edition. New Jersey: Prentice-Hall.

Greenley, G. \& Oktemgil M. 1998. 'A comparison of slack resources in high and low performing British companies', Journal of Management Studies, 35: 377-398.

Greve H. 2003. 'A behavioral theory of R\&D expenditures and innovations: Evidence from shipbuilding', Academy of Management Journal, 46(6): 685-702.

Hannan, M.T. \& Carroll, G.R. 1992. Dynamics of organizational populations: Density, legitimation, and competition. New York: Oxford University Press.

Hannan, M.T. \& Freeman, J. 1989. Organizational ecology. Cambridge: Harvard University Press.

Huselid, M.A. 1995. 'Impact of human-resource management-practices on turnover, productivity, and corporate financial performance', Academy of Management Journal, 38(3)635-672.

Jensen, M.C. \& Meckling, W.H. 1976. 'Theory of firm: Managerial behavior, agency costs, and ownership structure', Journal of Financial Economics, 3(4): 305-360.

Ju, M. \& Zhao, H. 2009. 'Behind organizational slack and firm performance in China: The moderating role of ownership and competitive intensity', Asia Pacific Journal of Management, 26: 701-717.

Kerin, R. A., Varadarajan, P. R. \& Peterson, R. A. 1992. 'First-mover advantage: A synthesis, conceptual framework, and research propositions', The Journal of Marketing, 56: 33-52.

Kim, H., Kim, H. \& P. Lee 2008. 'Ownership structure and the relationship between financial slack and $R \& D$ investments: Evidence from Korean Firms', Organization Science, 19: 404-418.

Koch, M. \& McGrath, R. 1995. 'Improving labor productivity: Human resource policies do matter', Strategic Management Journal, 17: 335-354.

Kor,Y. \& Mahoney, J. 2000. 'Penrose's resource based approach: The process and product of research creativity', Journal of Management Studies, 37: 109-140. 
Kornai, J. 1992. The socialist system. Princeton, N.J.: Princeton University Press.

Kroll, K.M. 2006. 'Repurposing metrics for HR', HR Magazine, 51(7): 65-69.

Li, G. \& Rajagopala, S. 1998. 'Process improvement, quality and learning effects', Management Science, 44: 1517-1532.

Li, H. \& Zhang, Y. 2007. 'The role of managers' political networking and functional experience in new venture performance: Evidence from China's transition economy', Strategic Management Journal, 28(8): 791-804.

Love, E. \& Nohria, N. 2005. 'Reducing slack: The performance consequences of downsizing by large industrial firms 1977-93', Strategic Management Journal, 26(12): 1087-1108.

Luo, Y. \& Peng, M.W. 1999. 'Learning to compete in a transition economy: Experience, environment, and performance', Journal of International Business Studies, 30(2): 269-296.

March, J.G. \& Shapira, Z. 1987. 'Managerial perspective risk and risk taking', Management Science, 33: 1404- 1418.

Markman, G.D. \& Gartner, W.B. 2002. 'Is extraordinary growth profitable? A study of Inc. 500 high-growth companies', Entrepreneurship theory and practice, 27(1): 65-75.

Mellahi, K. \& Wilkinson, A. 2010. 'A study of the association between level of slack reduction following downsizing and innovation output,' Journal of Management Studies, 47:483-508.

Miller, D., Lant, T., Millilum, F. \& Korn, H. 1996. 'The evolution of strategic simplicity: Exploring two models of organizational adoption', Journal of Management, 22: 863887.

Miller, K.D. \& Leiblein, M.J. 1996. 'Corporate risk-return relations: Return variability versus downside risk,' Academy of Management Journal, 39 (1): 91-122.

Mishina, Y., Pollock, T. \& Porac, J. 2004. 'Are more resources always better for growth? Resource stickiness in market and product expansion', Strategic Management Journal, 25: 1179-1197.

Mosakowski, E. 2002. 'Overcoming resource disadvantages in entrepreneurial firms: When less is more'. In Hitti, M.A. Ireland, R.D. Camp, S.M. and Sexton, D.L. (eds.) Strategic entrepreneurship: Creating a new integrated mindset. Oxford: U.K: Blackwell Publishers, p.p.106-126.

Ndofor, H. \& Levitas, E. 2004. 'Signaling the strategic value of knowledge', Journal of Management, 30: 685-702.
Nohria, N. \& Gulati, R. 1996. 'Is slack good or bad for innovation?' Academy of Management Journal, 39: 12451264.

Pang, C. Shen, H. \& Li, Y. 2011. 'How organizational slack affects new venture performance in China: A contingent perspective', Chinese Management Studies, 5(2): 181-193.

Peng, M.W. 2000. 'Managerial ties and firm performance in a transition economy: The nature of a micro-macro link', Academy of Management Journal, 43 (3): 486-501.

Peng, M.W. \& Heath, P.S. 1996. 'The growth of the firm in planned economies in transition: Institutions, organizations, and strategic choice', Academy of Management Review, 21(2): 492-528.

Peng, M.W., Li, Y., Xie, E. \& Su, Z. 2010. 'CEO duality, organizational slack, and firm performance in China. Asia Pacific Journal of Management, 27 (4): 611-624.

Peng, M.W., Tan, J. \& Tong, T.W. 2004. 'Ownership types and strategic groups in an emerging economy', Journal of Management Studies, 41(7): 1105-1129.

Perkins, D. 1994. 'Completing China's move to market', Journal of Economics Perspectives, 8(2): 23-46.

Pfeffer, J. \& Salancik, G. 1986. The external control of organizations. Marshfield, MA: Pitman.

Pitelis, C.N. 2007. 'A behavioral resource-based view of firms: Synergy of Cyert and March (1963) and Penrose (1959)', Organizational Science, 18(3): 478-498.

Quer, D., Claver, E. \& Rienda, L. 2007. 'Business and management in China: A review of empirical research in leading international journals', Asia Pacific Journal of Management, 24: 359-384.

Rust, K.G. \& Katz, J. P. 2002. 'Organizational slack and performance: The interactive role of workforce changes'. Paper presented in the strategic management track of the Midwest Academy of Management Conference, April 2002. [online] URL: http://www.midwestacademy.org/ Proceedings/2002/papers/Rust.doc .Accessed 15-03-2011.

Sharfman, M.P., Wolf, G., Chase, R.B. \& Tansik, D.A. 1988. 'Antecedents of organizational slack', Academy of Management Review, 13: 601-614.

Shenker, O. \& Von Glinow, M.A. 1994. 'Paradox of organizational theory and research: Using case of China to illustrate national contingency', Management Science, 40 (1): 56-71.

Shleifer, A. \& Vishney, R.W. 1994. 'Politicians and firms', Quarterly Journal of Economics, 109 (4): 995-1025. 
Starr, J. A. \& Macmillan, I. C. 1990. 'Resource cooptation via social contracting - resource acquisition strategies for new ventures', Strategic Management Journal, 11: 79-92.

Stevenson, H. H. 1983. 'A perspective on entrepreneurship'. Harvard Business School Working Paper No. 9-384-131. Boston: Harvard Business School.

Stevenson, H. H. \& Jarillo, J. C. 1990. 'A paradigm of entrepreneurship: Entrepreneurial management', Strategic Management Journal, 11: 17-27.

Su, Z., Xie, E. \& Li, Y. 2009. 'Organizational slack and firm performance during economic transitions', Asia Pacific Journal of Management, 26: 75-92.

Tan, J. 2002. 'Impact of ownership type on environment, strategy, and performance: Evidence from China,' Journal of Management Studies, 39(3): 333-354.

Tan, J. 2003. 'Curvilinear relationship between organizational slack and firm performance: Evidence from Chinese state enterprises', European Management Journal, 21(6): 740-749.

Tan, J. \& Peng, M.W. 2003. 'Organization slack and firm performance during the economic transition: Two studies from an emerging economy', Strategic Management Journal, 24 (13): 1249-1263.

Thompson, J. 1967. Organizations in action. New York: McGraw-Hill.

Tsai, B. H. 2008. 'Rights issues in China as Evidence for the existence of two types of agency problems', Issues \& Studies, 44 (3): 43-70.

Voss, G., Sirdeshmukh, D. \& Voss, Z. 2008. 'The effects of slack resources and environmental threat on product exploration and exploitation', Academy of Management Journal, 51: 147-164.

Wang, H., Choi, J., Wan, G. \& Dong, J.Q. 2013. 'Slack resources and the rent-generating potential of firm-specific knowledge', Journal of Management, in press.

Welbourne, T. M., Neck, H. M. \& Meyer, G. D. 1999. 'Human resource slack and venture growth: An exploratory analysis of growing employees at a faster rate than sales'. In Reynolds, P. D. Bygrave, W. D. Manigart, S. Mason, C. M. Meyer, G. D. Sapienza, H. J. Shaver, K. G. (eds.). Frontiers of entrepreneurship research 1999. Babson Park (MA): Babson College, p.p.480-490.

Wiersma, E. 2007. 'Condition that shape the learning curve: Factors that increase the ability and opportunity to learn', Management Science, 53(12): 1903-1915.

Williamson, I.O. 2000. 'Employer legitimacy and recruitment success in small businesses', Entrepreneurship Theory and Practice 25: 27-42.
Wiseman R.M. \& Bromiley, P. 1996. 'Toward a model of risk in declining organizations: An empirical examination of risk, performance and decline', Organization Science 7(5): 524-543.

Wrigh, M., FilatotChe, I., Hoskissio, R. \& Peng, M.W. 2005. 'Strategy research in emerging economies: Challenging the conventional wisdom', Journal of Management Studies, 42: 1-33.

Wu, J \& Pangakar, N. 2010. 'The bidirectional relationship between competitive intensity and collaboration: Evidence from China', Asia Pacific Journal of Management, 27: 503522.

Wu, J., Xu, D., \& Phan, P.H. 2011. 'The effects of ownership concentration and corporate debts on corporate divestitures in Chinese listed firms', Asia Pacific Journal of Management, 28: 95-114.

Wu, W., Wu, C. \& Rui. O.M.. 2010.'Ownership and the value of political connections: Evidence from China', European Financial Management, 18(4).

Yan, A. \& Gray B. 1994. 'Bargaining power management control and performance in US-China joint ventures: A comparative case study', Academy of Management Journal, 37: $1478-1517$.

Yelle, L.E. 1979. 'The learning curve historical review and comprehensive survey', Decision Science, 10: 302-328.

Zhang, Y. 2006. 'The presence of a separate $\mathrm{COO} /$ president and its impact on strategic change and CEO dismissal', Strategic Management Journal, 27: 283-300. 